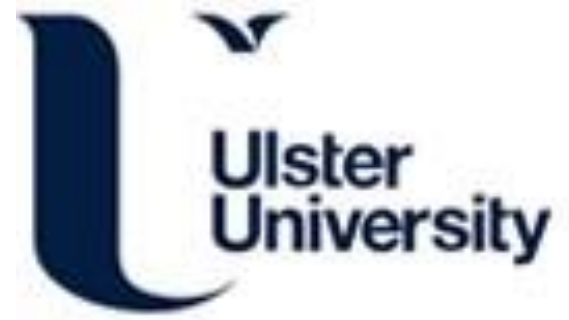

\section{Transfer of antibiotic resistance genes between Enterococcus faecalis strains in filter feeding zooplankton Daphnia magna and Daphnia pulex}

Olanrewaju, T. O., McCarron, M., Dooley, J., \& Arnscheidt, J. (2019). Transfer of antibiotic resistance genes between Enterococcus faecalis strains in filter feeding zooplankton Daphnia magna and Daphnia pulex. Science of the Total Environment, 659, 1168-1175. https://doi.org/10.1016/j.scitotenv.2018.12.314

Link to publication record in Ulster University Research Portal

\section{Published in:}

Science of the Total Environment

Publication Status:

Published (in print/issue): 01/04/2019

DOI:

10.1016/j.scitotenv.2018.12.314

\section{Document Version}

Author Accepted version

\section{General rights}

Copyright for the publications made accessible via Ulster University's Research Portal is retained by the author(s) and / or other copyright owners and it is a condition of accessing these publications that users recognise and abide by the legal requirements associated with these rights.

\section{Take down policy}

The Research Portal is Ulster University's institutional repository that provides access to Ulster's research outputs. Every effort has been made to ensure that content in the Research Portal does not infringe any person's rights, or applicable UK laws. If you discover content in the Research Portal that you believe breaches copyright or violates any law, please contact pure-support@ulster.ac.uk. 
Title: Transfer of antibiotic resistance genes between Enterococcus faecalis strains in filter feeding zooplankton Daphnia magna and Daphnia pulex

\section{Authors}

1. Temilola O. OLANREWAJU, School of Geography and Environmental Sciences, Ulster University, Cromore Road, Coleraine BT52 1SA, UK

2. Mary McCARRON, School of Biomedical Sciences, Ulster University, Cromore Road, Coleraine BT52 1SA, UK

3. James S. G. DOOLEY, School of Biomedical Sciences, Ulster University, Cromore Road, Coleraine BT52 1SA, UK

4. Joerg ARNSCHEIDT, School of Geography and Environmental Sciences, Ulster University, Cromore Road, Coleraine BT52 1SA, UK

Corresponding author: Dr. Joerg Arnscheidt

Address: School of Geography and Environmental Sciences, Faculty of Life and Health

Sciences, Ulster University, Cromore Road, Coleraine BT52 1SA UK

Telephone: +44 2870124095

Email: j.arnscheidt@ulster.ac.uk 


\begin{abstract}
Antibiotic resistant bacteria from faecal pollution sources are pervasive in aquatic environments. A facilitating role for the emergence of waterborne, multi-drug resistant bacterial pathogens has been attributed to biofiltration but had not yet been substantiated. This study investigated the effect of filtration and gut passage in Daphnia spp. on conjugal transfer of resistance genes in Enterococcus faecalis. In vivo conjugation experiments involved a vancomycin-resistant donor strain bearing a plasmid-borne vanA resistance gene, and two vancomycin-susceptible and rifampicin-resistant recipient strains in the presence of Daphnia magna or Daphnia pulex. Results showed successful transfer of the vanA resistance gene from donor to recipient; gene identity was confirmed by PCR and DNA sequencing. There was no significant difference in the number of transconjugants recovered from D. magna and D. pulex. However, transconjugant numbers differed by one order of magnitude between recipient strains. Transconjugant numbers from D. magna were also significantly different between treatments with ingestion of individual phytoplankton species before filtration of bacteria. The highest transfer efficiency calculated from excreted transconjugants was $2.5 \times 10^{-6}$. This proof of concept for facilitation of horizontal gene transfer by a filter feeding organism provides evidence that Daphnia can disseminate antibiotic resistant transconjugants in the environment.
\end{abstract}

\title{
Keywords
}

Daphnia, antimicrobial resistance, vanA gene, conjugation, bacteria, Enterococcus faecalis 


\section{Introduction}

The emergence of antibiotic resistance has been designated as a global health threat of major clinical and environmental relevance (1). Opportunistic bacterial pathogens are the main cause of healthcare associated infections (HAIs) and the frequent failure of antibiotic treatments is the result of multiple resistance genes expressed by these pathogens (2). Aquatic environments appear as suitable conduits for such microorganisms (3), because bacteria with antibiotic resistance and their genes are able to persist in lakes $(4)$, rivers $(5,6)$ and estuaries $(7)$ where they are often strongly associated with anthropogenic activities like discharges from wastewater treatment plants and agricultural sources. Although it is to be expected that antibiotic residues released into aquatic ecosystems can generate a selection pressure that allows antibiotic resistant bacteria to thrive and spread (8), inherent system complexity poses an immense challenge for any test of the hypothesis that these environments play a role in the spread and emergence of such resistance. Even wastewater treatment facilities with their tight technical controls have remained black boxes in this respect (9).

While mechanisms of resistance in bacteria are well known, the increased frequency with which multiresistant bacteria are identified in hospitals has motivated concerted efforts to understand the environmental processes facilitating the emergence and rapid spread of antibiotic resistance (2). There have been repeated suggestions that filter feeding aquatic invertebrates have the potential to drive the ecology and evolution of antibiotic resistance in aquatic ecosystems $(10,11)$. Freshwater cladoceran zooplankton species of the genus Daphnia are filter feeders that play a central role in the food webs of lakes and ponds as consumers of bacterioplankton and phytoplankton and as prey of invertebrate and fish predators. Bacteria can form a major component in Daphnia nutrition (12) and those present in the gastrointestinal tract can have a symbiotic effect on Daphnia growth, survival and reproduction (13).

Horizontal transfer of mobile genetic elements (MGEs) such as plasmids and transposons, which encode virulence and antimicrobial resistance in microbial populations, is a widely occurring phenomenon (14). 
Between environmental bacteria such a genetic exchange is often accomplished through conjugation (15). If it occurs in the intestine of a host organism $(16,17)$, bacteria with newly acquired MGEs can be spread in the environment through faecal deposition (18), which can thus facilitate the dissemination of newly emerging bacterial pathogens with multiple antibiotic resistance genes.

Enterococci are Gram-positive, facultative anaerobic bacteria that form an important component of the gut microbiota of animals $(19,20)$. They support digestion and other metabolic processes and can boost immunity in hosts (21). They are also opportunistic pathogens known to cause HAIs on a global scale (22). Due to their widespread occurrence in both terrestrial and aquatic ecosystems, largely through human and animal faeces, they are widely utilised as indicators of environmental faecal contamination (23). Enterococcus strains increasingly express multiple resistance to antibiotics (24). A pheromoneinduced conjugal transfer of resistance genes has been identified within the Enterococcus genus (25). In Enterococcus faecalis conjugation can transfer plasmids that carry genes encoding for vancomycin resistance from donor cells to pheromone-secreting recipients from the same bacterial species (26). Recently the potential for this genetic exchange to occur in living organisms has been reported for a murine model (27). However, very little is known about conjugal gene transfer rates within living organisms that experience episodic or periodic exposure to E. faecalis particularly in aquatic environments.

This study determines if pheromone-induced conjugation between E. faecalis strains occurred within the gastrointestinal tract of two Daphnia species. Results showed that the transfer of a vancomycin resistance gene from resistant to susceptible strains of E. faecalis occurred during a period of active filtration by Daphnia species. Thus, it represents the first proof of concept that filter feeding freshwater organisms may facilitate conjugal resistance gene transfer in waterborne bacteria. 


\section{Materials and Methods}

\section{Test organisms}

Daphnia magna and Daphnia pulex clones were acquired commercially from Sciento Scientific Ltd, Manchester, UK, and Blades Biological Ltd, Kent, UK respectively. Batches of adult daphnids (2.2 - 2.6 $\mathrm{mm}$ ) were then cultured continuously in filtered and autoclaved river water in $5 \mathrm{~L}$ containers at $20^{\circ} \mathrm{C}$ under a 12:12 h light:dark regime. Daphnids were fed with green algae (Desmodesmus subspicatus or Palmellopsis sp. from the SAG culture collection at the University of Goettingen Germany, strain numbers: SAG 86.81 and 52.90 respectively); algal cultures were maintained at room temperature (21 \pm 2 ${ }^{\circ} \mathrm{C}$ ). The river water was renewed twice a week, and neonates were recovered and used to start new cultures during each renewal. The concentration of algal cells was determined with a hemocytometer at 40x magnification under a light microscope. Before application in feeding the daphnids, algal suspensions were diluted to a concentration of $2.0 \times 10^{6} \mathrm{~N} / \mathrm{mL}$. Clones of adult daphnids from each batch were collected and sorted according to size for use in conjugation experiments.

\section{Bacterial strains and reagents}

Two environmental E. faecalis isolates (MF06036 ${ }^{\mathrm{Van}}$, MW01105 ${ }^{\mathrm{Rif}}$ ) used in this study have been previously identified and described $(26,28)$. Genotypic identification of bacterial strains was carried out by DNA extraction, 16S rDNA gene amplification using the polymerase chain reaction followed by DNA sequencing. Bacterial cultures were maintained on Tryptone Soya Agar (TSA, Oxoid, CM0131, Basingstoke, England) at $4{ }^{\circ} \mathrm{C}$ for the duration of the experiment. Overnight bacterial cultures used for conjugation experiments were grown in Tryptone Soy Broth (TSB, Oxoid CM0129, Basingstoke, England) at $37{ }^{\circ} \mathrm{C}$. Vancomycin and rifampicin used for the experiments were obtained from SigmaAldrich (St. Louis, USA). 


\section{Selection for rifampicin resistance in recipient strains}

Counter-selection of vancomycin resistance genes transferred from a donor to a recipient was facilitated by introducing rifampicin resistance into the vancomycin sensitive recipient strains. To achieve this, cultures of the pheromone-producing recipients were grown in sub-minimum inhibitory concentrations of rifampicin which were eventually scaled up to $512 \mathrm{mg} / \mathrm{L}$ as previously described (26). At the end of antibiotic exposure treatments, recipients were resistant to $512 \mathrm{mg} / \mathrm{L}$ rifampicin (denoted as MW01105 ${ }^{\text {Rif }}$ and $\mathrm{ST} 02103^{\mathrm{Rif}}$ ) while the donor was susceptible to rifampicin and resistant to vancomycin (denoted as MF06036 $\left.{ }^{\mathrm{Van}}\right)$.

\section{Antimicrobial disk diffusion assay}

E. faecalis isolates $\mathrm{MF} 06036^{\mathrm{Van}}$, $\mathrm{ST} 02103^{\mathrm{Rif}}$ and ${\mathrm{MW} 01105^{\mathrm{Rif}}}_{\text {were }}$ tested for the presence of antimicrobial resistance phenotypes using the disk diffusion assay. Results were interpreted according to the European Committee on Antimicrobial Susceptibility Testing (EUCAST) guidelines (29) and Clinical \& Laboratory Standards Institute (CLSI) guidelines (30). A 16-hour culture of bacteria grown in TSA was re-suspended in PBS to the MacFarland 0.5 standard. The suspension was spread on the surface of a dried Muller Hinton agar (MHA) plate with a sterile swab. Antibiotic disks (Oxoid) were stamped on the plates using a disk dispenser (Oxoid). The antibiotics in the assay were ciprofloxacin $(5 \mu \mathrm{g})$, imipenem $(10 \mu \mathrm{g})$, linezolid $(10 \mu \mathrm{g})$, rifampicin $(5 \mu \mathrm{g})$, streptomycin $(300 \mu \mathrm{g})$, trimethoprim $(5 \mu \mathrm{g})$, teicoplanin $(30 \mu \mathrm{g})$, and vancomycin $(30 \mu \mathrm{g})$. Plates were incubated for $24 \mathrm{~h}$ at $37^{\circ} \mathrm{C}$. Zones were measured $(\mathrm{mm})$ and compared to EUCAST and CLSI guidelines. E. faecalis ATCC 29212 was used as a susceptibility control.

\section{Determination of Daphnia length}

Before the conjugation experiments, large Daphnia specimens were collected from the culture by filtration through a nylon mesh (aperture size $730 \times 1520 \mu \mathrm{m}$ ) and were transferred to microcosms with 
disposable pipettes. Standard length from the eye to the base of the apical spine (31) was determined on digital images for each individual using an OLYMPUS microscope and imaging suite (optical microscope SZX16 with a DP72 camera and imaging software cellSens 1.3, all by OLYMPUS Co, Japan).

\section{Clearance of Daphnia gut content}

Prior to exposure to the test bacteria, gut contents of selected daphnids were cleared by starvation treatment for 2 days. Afterwards, daphnids were fed with $300 \mu \mathrm{L}$ of sterile Sephadex G-25 (cross-linked dextran gel) medium (GE HealthCare, UK) three times a day for a further $72 \mathrm{~h}$ to achieve gut clearance (32). A Sephadex stock mixture was prepared by adding approximately $0.5 \mathrm{~g}$ of powder per $100 \mathrm{~mL}$ of autoclaved Daphnia medium.

\section{Determination of Daphnia filtration rate for bacteria}

Bacteria grazing experiments were conducted with adult Daphnia magna $($ mean body length $1.8 \mathrm{~mm}, \mathrm{n}=$ 10) and adult $D$. pulex (mean body length $1.9 \mathrm{~mm}, \mathrm{n}=10$ ). The coefficient of variation in daphnid length

was kept below 4\%. Prior to the grazing experiment, daphnids were placed in sterile reconstituted Daphnia medium (DM) prepared as ISO test water according to OECD, 2004, Annex 3 (33) and starved for $3 \mathrm{~d}$ at $20^{\circ} \mathrm{C}$. DM was renewed daily and the daphnids were checked for mortality. To determine the filtration rate of the two Daphnia species, samples of 10 daphnids in $10 \mathrm{~mL}$ DM were inoculated with 1.5 $\mathrm{x} 10^{9} \mathrm{cfu} / \mathrm{mL}$ of $E$. faecalis for $24 \mathrm{~h}$ in the dark.

Concentrations of bacteria were determined through counts of colony forming units (cfu); filtration rates were calculated with the equation (34):

$$
\text { Filtration rate }\left(m L \text { animal }^{-1} h^{-1}\right)=\frac{1}{t} \times \ln \left(C_{0} / C_{t}\right) \times \frac{v}{N}
$$

Where $\mathrm{t}=$ duration of feeding, $\mathrm{C}_{\mathrm{o}}$ is the concentration of bacteria at time, $\mathrm{t}=0 \mathrm{~h}, \mathrm{C}_{\mathrm{t}}$ is the concentration of bacteria at time, $\mathrm{t}=24 \mathrm{~h}, \mathrm{v}=$ volume of treatment, $\mathrm{N}=$ number of daphnids 


\section{Conjugal transfer of vancomycin resistance within the Daphnia gut}

To investigate the effect of filtration on the transfer of vancomycin resistance, samples with 10 daphnids each were used for the conjugation experiments. These were placed in $30 \mathrm{~mL}$ universal tubes (Greiner bio-one Inc., Austria) and incubated in $10 \mathrm{~mL} \mathrm{DM}$ at $20{ }^{\circ} \mathrm{C}$ for $24 \mathrm{~h}$ in the dark to acclimatise with the experimental conditions. For experiments 1 and 2 all daphnids were starved during this period to ensure that they fed at a higher rate during the main experiment; for experiments 3 and 4 only daphnids in control samples were starved, while specimens in treatment samples had been fed either with phytoplankton species Palmellopsis sp. or Desmodesmus subspicatus.

Aliquots of $1 \mathrm{~mL}$ overnight culture of E. faecalis recipient strain (MW01105 ${ }^{\text {Rif }}$ or ST02103 ${ }^{\text {Rif }}$ ) and donor strain MF06036 ${ }^{\text {Van }}$ were each diluted with $9 \mathrm{~mL}$ TSB and cultivated in $15 \mathrm{~mL}$ centrifuge tubes for $90 \mathrm{~min}$ at $37^{\circ} \mathrm{C}$ to enter the mid-exponential growth phase. The bacterial cells were harvested by centrifugation for $30 \mathrm{~min}$ at $2300 \mathrm{~g}$ at $4{ }^{\circ} \mathrm{C}$. The supernatant was discarded, and the bacterial pellet resuspended in 10 mL DM. $500 \mu$ of resuspended 90 min culture was added to $4.5 \mathrm{~mL}$ of sterile $\mathrm{DM}$ in $30 \mathrm{~mL}$ universal tubes to make a $10 \%$ bacterial treatment. For initial acclimatisation to the bacteria diet, seven samples of 10 adult Daphnia in $10 \%$ recipient strain treatment were incubated for $1 \mathrm{~h}$ at $20{ }^{\circ} \mathrm{C}$ in the dark. Afterwards, daphnids were removed with a transfer pipette, washed twice in $5 \mathrm{~mL} \mathrm{DM}$ and then transferred to new $30 \mathrm{~mL}$ tubes containing sterile $4.5 \mathrm{~mL}$ DM for the feeding-conjugation experiment. Control samples of Daphnia in DM without bacterial inoculation were also set up to ensure that no enterococci were introduced by the daphnids.

For feeding-conjugation experiments, $1 \mathrm{~mL}$ of $\mathrm{MF} 06036^{\mathrm{Van}}$ was added to $9 \mathrm{~mL}$ of recipient strain (MW01105 ${ }^{\text {Rif }}$ or ST02103 ${ }^{\mathrm{Rif}}$ ), all in the mid-exponential phase, and gently mixed (26). A $500 \mu$ l aliquot of the mix was then added to $4.5 \mathrm{~mL} \mathrm{DM}$ in the $30 \mathrm{~mL}$ tubes containing the washed daphnids and incubated at $20{ }^{\circ} \mathrm{C}$ for a further $4 \mathrm{~h}$ in the dark to allow filtration. The bacterial concentration was kept the same as it 
had been during the acclimatisation step. Daphnids were then removed from the feeding treatment, washed in $5 \mathrm{~mL}$ DM twice and then transferred to $30 \mathrm{~mL}$ universal tubes containing $4.5 \mathrm{~mL} \mathrm{DM}$ and 500 $\mu \mathrm{L}$ of recipient strain. Then the treatment was incubated at $20^{\circ} \mathrm{C}$ for another $2 \mathrm{~h}$ to allow for the clearance of the gut content from the previous $4 \mathrm{~h}$ feeding step. Seven samples of treatments and controls containing no daphnids were prepared for the feeding and gut clearance steps. At the end of both phases, double selection TSA plates were inoculated with $500 \mu \mathrm{L}$ of the treatment and controls and incubated at $37^{\circ} \mathrm{C}$ for $48 \mathrm{~h}$. TSA selection plates were prepared with $10 \mu \mathrm{g} / \mathrm{mL}$ vancomycin and $100 \mu \mathrm{g} / \mathrm{mL}$ rifampicin (26). As a negative control, double selection TSA plates were inoculated with parent strains to confirm the effect of the antibiotic concentrations. After the $48 \mathrm{~h}$ incubation period, the transconjugants (TC) excreted by daphnids were counted as cfu numbers and the vancomycin transfer efficiency was calculated (number of transconjugants per donor; number of transconjugants per recipient). The concentration of donor and recipient strain fed to the daphnids was determined by direct plate count after a 6-fold serial dilution.

\section{PCR amplification of vancomycin resistance genes in donor and transconjugants}

The vancomycin resistance gene target sequence was amplified using a TC-5000 Techne Thermal Cycler gradient PCR instrument (GMI, Inc, USA) following a previously described method (26). Briefly, 120 $\mathrm{ng} / \mu \mathrm{L}$ of Enterococcus DNA was mixed with $49 \mu \mathrm{L}$ of master mix, with a final concentration of $1.5 \mathrm{mM}$ $\mathrm{MgCl}_{2}, 0.2 \mathrm{mM}$ (each) deoxynucleoside triphosphate, $0.5 \mu \mathrm{m}$ of vanA forward (5'-CTACTCCCGCCTTT TGGCTT-3') and vanA reverse (5'-TTCACACCGAAGGATGAGCC-3’) primer sequences and $2.5 \mathrm{U}$ of Taq DNA polymerase (Invitrogen Corp., California, USA). An initial denaturation step at $95^{\circ} \mathrm{C}$ for 5 min was followed by 30 cycles of denaturation at $94{ }^{\circ} \mathrm{C}$, annealing of PCR primers at $58{ }^{\circ} \mathrm{C}$ for $30 \mathrm{~s}$, DNA extension at $72{ }^{\circ} \mathrm{C}$ for $90 \mathrm{~s}$ and a final incubation step at $72{ }^{\circ} \mathrm{C}$ for $10 \mathrm{~min}$. Afterwards, the PCR fragments were held continuously at $4{ }^{\circ} \mathrm{C}$. They were analysed by electrophoresis in TBE buffer $(1 \%$ Tris-Borate EDTA) in a 1.5\% (wt/vol) agarose gel stained with $5 \mu \mathrm{L}$ SYBR safe at 100 volts. Gels were visualized on an Alpha Imager (Cell Biosciences, Heidelberg, Germany). 


\section{DNA sequencing and analysis}

Sanger sequencing of the amplified vanA sequence was performed by Eurofins Genomics GmbH (Germany). Nucleotide sequences of both forward and reverse strands of PCR products were determined using the vanA forward and reverse primers respectively. The nucleotide sequence data were aligned and edited using the BioEdit software alignment editor. The Basic Local Alignment Search Tool (BLAST) program was used to carry out a similarity search on sequence data held on the National Centre for Biotechnology website. For generating an identity similarity matrix, donor and transconjugant nucleotide sequence similarity was determined in public databases with the BLAST program (http://www.ncbi.nlm.nih.gov /blast/) and T-COFFEE multiple sequence alignment program (http: www.ebi.ac.uk/Tools/msa/tcoffee/).

\section{Statistical analysis}

Differences between transconjugant numbers in experimental treatments were determined by one-way analysis of variance after a test of normal distribution using the Kolmogorov Smirnov test. Statistical analysis of data was conducted using the GraphPad Prism 7.00 software. To determine the effective sample size for this study, a power analysis was carried out with the GPower 3.1 software and data from an initial pilot experiment with 11 samples. It revealed that six samples were sufficient to detect a significant difference of up to $20 \%$ of the mean between groups, at alpha $=0.05$ and power $=0.8$ for two treatments. 


\section{Results}

\section{Antibiotic resistance profile of enterococci strains}

The isolates selected for this study were tested for resistance to eight antibiotics. The donor strain MF06036 ${ }^{\mathrm{Van}}$ and the recipient strain ST02103 ${ }^{\mathrm{Rif}}$ were resistant to three antibiotics; the recipient strain MW01105 ${ }^{\text {Rif }}$ was resistant to two antibiotics (Table 1). The antibiotic susceptibility test confirmed vancomycin resistance in the donor and vancomycin susceptibility in the recipients.

\section{Bacteria filtration rate}

The filtration rates of $D$. magna and D. pulex for the recipient E. faecalis strains were individually assessed after gut clearance (Table 2). Fig. 1 shows an adult Daphnia magna before and after the gut evacuation phase, and prior to the determination of bacterial filtration rates. The loss of green colour indicates clearance of algal food from the gut. Student's t-test for independent samples showed no significant difference between the mean filtration rates of two different Enterococcus strains, MW01105 $^{\text {Rif }}$ and ST02103 ${ }^{\text {Rif }}$ by D. magna $(t=0.043, d f=4, \mathrm{n}=3, p=0.968)$ and by $D$. pulex $(t=$ 0.7879, $d f=4, \mathrm{n}=3, p=0.4748)$. When the filtration rates were compared between the two Daphnia species, results showed no significant differences between $D$. magna and $D$. pulex in their filtration of $\operatorname{MW01105}^{\mathrm{Rif}}(F=7.018, d f=2, p=0.5859)$ and ST02103 ${ }^{\mathrm{Rif}}(F=2.387, d f=2, p=0.5904)$ respectively.

\section{Determination of vancomycin resistance transfer within the Daphnia gut}

The concentrations of the donor MF06036 $6^{\text {Van }}$ and recipient strains MW01105 ${ }^{\text {Rif }}$ and ST02103 ${ }^{\text {Rif }}$ (hereafter referred to as parent strains) used in the D. magna and D. pulex conjugation experiments (Table 3 ) were not significantly different (Kruskal-Wallis, $\mathrm{H}=4.244, d f=5, p=0.1189$ for experiment $1 ; \mathrm{H}=0.2152$, $d f=5, p=0.9100$ for experiment 2). This was a prerequisite for ensuring comparability of gene transfer rates for the different Daphnia species and recipient E. faecalis strains used in this study. For D. magna 
there was a significant difference of TC numbers on double antibiotic TSA plates between recipient strains (Mann Whitney $\mathrm{U}=0.5, \mathrm{n}_{1}=7, \mathrm{n}_{2}=7, p=0.0012$ ) with the TC number from ST02103 ${ }^{\text {Rif }}$ being fifteen times higher than the TC number from MW01105 ${ }^{\text {Rif }}$.

Similarly, there was a significant difference in the D. pulex conjugation experiments with ST02103 ${ }^{\text {Rif }}$ strain producing TC about twelve times more than TC from MW01105 ${ }^{\text {Rif }}$ (Mann Whitney $\mathrm{U}=0, \mathrm{n}_{1}=7, \mathrm{n}_{2}$ $=7, p=0.0006$ ). In experiments with both Daphnia species (Table 3), the efficiency of vancomycin resistance transfers in ST02103 ${ }^{\text {Rif }}$ consistently exceeded that in MW01105 ${ }^{\text {Rif }}$ by one order of magnitude $\left(10^{-7}\right.$ to $\left.10^{-8}\right)$, while differences in number of TC obtained between Daphnia species were not significant (Mann-Whitney $\mathrm{U}=20, \mathrm{n}_{1}=7, \mathrm{n}_{2}=7, \mathrm{p}=0.6002$ for MW01105 ${ }^{\text {Rif }} ; \mathrm{U}=12, \mathrm{n}_{1}=7, \mathrm{n}_{2}=7, \mathrm{p}=0.1265$ for ST02103 $3^{\text {Rif }}$.

In experiments 3 and 4 there were significant differences in TC numbers (Kruskal-Wallis, $\mathrm{H}=13.22, d f=$ $5, \mathrm{p}=0.0001$ for experiment 3; $\mathrm{H}=14.3, d f=5, \mathrm{p}<0.0001$ for experiment 4, Fig. 3) between diets of individual phytoplankton species fed to D. magna before the latter's exposure to E. faecalis. Transfer efficiencies in Palmellopsis treatments exceeded those in Desmodesmus treatments by one order of magnitude; the maximum transfer efficiency was $2.5 \times 10^{-6}$ (transconjugant: donor, table 4).

The confidence in these numbers being an adequate representation of obtainable TC numbers from the Daphnia stems from $\geq 80 \%$ of $\mathrm{TC}$ emerging in the feeding phase of the experiments, in all but two treatmentsof experiment 3. The usually much lower number obtained during the gut clearance phase (Tables 3 and 4). The confidence in these numbers being an adequate representation of obtainable TC numbers from the Daphnia stems from more than $90 \%$ of TC emerging in the feeding phase of the experiments. The much lower number obtained during the gut clearance phase showed that most of the excretion of the filtered and ingested bacteria from the Daphnia gut had already happened within the initial $4 \mathrm{~h}$ feeding phase before the daphnids were transferred into gut clearance containers and suggested a steep decline in excretion rates after feeding stopped. Re-ingestion of enterococci after excretion appeared unlikely, as faecal pellets remained physically intact. Controls with bacterial parent strains but 
without Daphnia produced no transconjugants in the time periods of the feeding phase and the gut clearance phase. Also, no growth was found on plates inoculated with control treatments containing only daphnids but no bacteria. TC colonies were further subcultured onto double selection TSA plates and single selection TSA plates with vancomycin $(10 \mu \mathrm{g} / \mathrm{mL})$ to confirm the acquisition of vancomycin resistance. After $24 \mathrm{~h}$ incubation at $37^{\circ} \mathrm{C}$ transconjugant growth was observed on the double selection plate and single selection plates as expected.

\section{PCR detection of vancomycin resistance genes in donor and transconjugants}

The identification of a known vancomycin resistance gene by PCR was used to confirm the transfer of vancomycin resistance between the donor and recipient strains. The phenotypical expression of vancomycin resistance was observed from transconjugant growth on double selection TSA plates. The

presence of a vanA gene was tested for in the donor MF06036 ${ }^{\mathrm{Van}}$, recipient strains MW01105 $5^{\mathrm{Rif}}$ and ST02103 ${ }^{\text {Rif }}$, and transconjugants recovered from D. magna and D. pulex respectively. The vanA resistance gene was present in the donor strain and all transconjugants but not in the two parental recipient strains (supplementary material).

\section{DNA sequencing and analysis}

The PCR amplified vanA for the donor MF06036 $6^{\mathrm{Van}}$ and transconjugants recovered from MW01105 ${ }^{\mathrm{Rif}}$ were sequenced and subjected to a sequence similarity search with BLAST. The vanA gene sequence similarity search gave a $100 \%$ match to a vanA gene in E. faecalis strain CU709 (GenBank accession number MG460317). The multiple alignment of the donor and transconjugant vanA gene sequence data was used to produce a percent identity matrix. The donor gene sequence had a $100 \%$ similarity to all transconjugant nucleotide sequences. There was also a $100 \%$ identity similarity in vanA gene sequence of 
transconjugants recovered from MW01105 ${ }^{\text {Rif }}$ and ST02103 ${ }^{\text {Rif }}$ in both $D$. magna and D. pulex experiments. This piece of direct evidence confirmed that the vancomycin resistance expressed by the recipient $E$. faecalis strains was due to the acquisition of the vanA gene as daphnids actively filtered bacteria.

\section{Discussion}

We hypothesized that freshwater zooplankton may facilitate the transfer of antibiotic resistance genes in pathogenic bacteria through their filter feeding. This required initial tests of Daphnia filtration rates in our microcosms for comparisons between the two species involved and with results from previous studies. While algae are the primary food for daphnids (35), bacteria are an important component of their diet in natural ecosystems and may even be preferentially digested compared to algae (12). In this study, we successfully demonstrated Daphnia filtration of E. faecalis in our laboratory system. We achieved rates comparable to results reported for D. magna and D. pulex (36), but they were lower than rates reported in another study for D. pulex (34), and for D. galeata (37). Such differences could be due to the type and size of the bacterial cells, the experimental conditions, e.g. inclusion or exclusion of dead and viable but non-culturable cells, and the size of the daphnids in the experiments undertaken by the different researchers (38). Filtration rate in Daphnia is generally proportional to body size, with larger filter mesh size of the filtering appendages of adult daphnids resulting in lower retention of bacteria than by juvenile specimens (36, 38, 39). In this study body size and bacteria filtration rates of the two Daphnia species were not significantly different. Therefore, species or size difference did not affect the acceptance of Enterococcus for ingestion.

In experiments involving exposure to both parent strains, filtration by Daphnia and subsequent intestinal passage resulted in the transfer of vancomycin resistance from donor to recipient strains of E. faecalis. Both Daphnia species were fed with a vancomycin-resistant donor and two different vancomycin- 
susceptible recipients. Successful conjugation was detected within a 4-h feeding period with transconjugants expressing resistance to vancomycin and rifampicin. The one-order of magnitude difference in transfer efficiency between recipient strains showed that individual strains of E. faecalis varied in their levels of competence for the acquisition of foreign resistance-gene-carrying plasmids, which may be due to differences in the pheromone-induced conjugation function of recipient strains observed in other studies $(26,40)$.

A 2-h gut clearance phase was introduced in the absence of the donor strain to confirm the emergence of transconjugants from the Daphnia gut and obtain any remaining transconjugants within the gut after the initial 4-h feeding. In this period, no transconjugants were obtained from both D. magna and D. pulex for MW01105 ${ }^{\text {Rif }}$ while transconjugant numbers from ST02103 ${ }^{\text {Rif }}$ were only about $4 \%$ of the number recovered from the 4-h feeding phase in both Daphnia species. As all experimental conditions were the same in trials with individual recipient strains and considering that most excretion of transconjugants had occurred during the feeding phase, the most likely cause for the significantly higher transconjugant numbers obtained from the ST02103 ${ }^{\text {Rif }}$ strain could be its more enhanced pheromone-induced genetic function. Yet, it should also be noted that it can be difficult to determine if the transconjugant numbers were the product of several transfer events or a single event followed by multiple cell division. Prolonged experimental periods can affect the accurate determination of transfer efficiency due to bacterial cell death and the transconjugants can also act as donors of vancomycin resistance plasmids as soon as they emerge in the water (41). In an attempt to at least constrain the frequency of occurrence for the latter event type, the length of experiments in this study was limited to a previously recommended 4-h period for the detection of early conjugation events (41).

For MW01105 ${ }^{\text {Rif }}$, as the only strain for which published data were available for comparison, vancomycin resistance transfer efficiencies $\left(10^{-8}\right)$ in Daphnia without recent phytoplankton ingestion were five magnitudes lower than values reported for transconjugants obtained from a solid-plate mating study (26). In vitro conjugation is usually studied under optimised conditions. The intestinal environment of Daphnia 
differs significantly from the latter in several respects, e.g. with a far lower ambient water temperature, exposure of parent strains and transconjugants to digestive enzymes from Daphnia and a relatively short gut residence time for ingested bacteria. Therefore, in vivo within Daphnia much lower transfer efficiencies are to be expected. Nevertheless, our experiments with Daphnia on diets of different phytoplankton species demonstrate that conjugal transfer efficiencies in filter feeders may increase by orders of magnitude depending on the type of food particles ingested in addition to bacteria. In this respect it is noteworthy that experiments 3 and 4 only involved the less efficient of the two E. faecalis recipient strains. Thus, it is very likely that further efficiency gains can be achieved.

Our study investigated the transfer of vancomycin resistance genes to E. faecalis strains resistant to rifampicin but susceptible to vancomycin. The vanA gene was identified in the donor strain MF06036 ${ }^{\text {Van }}$ and in the transconjugants recovered from D. magna and D. pulex. The acquisition of vancomycin resistance in $E$. faecalis has been linked with plasmid-mediated vanA-type phenotypes isolated from dairy products (42). Intraspecies transfer of vanA plasmids in Enterococcus has a much higher success rate than interspecies transfer (41). However, the possibility of interspecies transfer cannot be dismissed. Transfers of vanA genes from animal to human enterococci isolates have been observed in a murine model (43), while authors of an in vitro conjugation study reported the transfer of vanA genes from clinical vancomycin resistant Enterococcus to Staphylococcus aureus (44). The propensity of emerging bacterial pathogens like enterococci to acquire new antibiotic resistance genes (45) should be motivation for technical upgrades of wastewater treatment facilities, to minimize the discharge of such bacteria. The donor strain used in this study has been previously characterised (26) and carried the vanA gene whose presence was also confirmed in all transconjugants by DNA amplification. While the previous laboratory study had investigated conjugal transfer of resistance genes between our parental strains on solid-plate media, the current study has gone a step further to show that in ecologically relevant systems, such conjugal gene transfer events can also occur within filter feeding organisms. 
The few investigations of the horizontal transfer of resistance genes within the gut of non-mammals have usually been carried out with Gram-negative bacteria, e.g. the conjugal transfer of multi-resistance carrying RP-4 plasmids in Escherichia coli within the gut of cockroaches (46), and an RP-4 plasmidmediated conjugation in the intestinal tract of zebrafish (17). There is recent evidence for an, albeit weak, accumulation of antibiotic resistance genes in filter feeders; in a stable environment such accumulation in marine mussels quickly appears to reach a low-level steady state (47). Also, Daphnia, presumably through filter feeding, can harbour antibiotic resistance genes within its microbiome (48). But previous research has not provided any evidence of conjugal resistance gene transfer occurring within the intestinal environment of Daphnia or any other crustaceans.

In this study however, we showed that transconjugants from the rifampicin-resistant recipient $E$. faecalis strains received the vanA gene as they passed through the Daphnia gut. The absence of transconjugants from the controls and significant numbers of transconjugants in treatments with actively filter feeding Daphnia confirmed the effect of filtration and gut intestinal passage with its compaction increasing the likelihood of conjugal cell contact between donor and recipient strains. Identical vanA gene nucleotide sequences from donor cells and transconjugants are evidence that a plasmid-mediated resistance gene transfer was responsible for the expression of vancomycin resistance phenotypes in the rifampicinresistant E. faecalis strains. Ingested enterococci may acquire multiple resistance in Daphnia, as this filter feeding organism has already been identified as a potential reservoir of resistance genes (48). As enterococci are sufficiently hardy to leave the gut environment unharmed (45), there is the possibility of wide dissemination of Enterococcus transconjugants by Daphnia with newly acquired resistance genes. These zooplankton organisms occupy central positions in aquatic food webs, where they can achieve densities of more than hundred individuals per litre (49), concentrate bacteria through filtration and are prey for higher order consumers. With this proof of concept of the facilitation of antibiotic resistance transfer by aquatic filter feeders, potential health risks may apply to other aquatic food chains, where humans are end consumers of filter feeders or their predators. 


\section{Conclusion}

Our study has provided the first direct evidence that filter feeding Daphnia can facilitate the horizontal transfer of antibiotic resistance genes in pathogenic bacteria of clinical relevance. The Daphnia gut proved to be a suitable mating environment for pheromone-induced intraspecies conjugal transfer of vancomycin resistance genes in E. faecalis. The facilitating role of Daphnia for bacterial conjugation was not species-specific, as transfer efficiencies in D. magna and D. pulex were comparable and may thus apply to many other Daphnia species. The evidence, that horizontal transfer of antibiotic resistance within Daphnia can be successful, holds important implications for aquatic environments with large Daphnia populations, which are directly impacted by faecal pollution sources. Exposure of Daphnia species as 'mobile incubators' for enterococci from anthropogenic sources increases the likelihood of further acquisition of new resistance genes by these emerging pathogens. Proactive wastewater management should therefore consider the implementation of technical measures to minimize the presence of antibiotic resistant bacteria in wastewater treatment effluent discharges into the natural environment.

\section{Acknowledgements}

The authors thank the Ulster University Doctoral College for funding this research through a ViceChancellor's Research Scholarship for T. Olanrewaju and the Northern Ireland Department of Employment and Learning for funding the PhD scholarship of M. McCarron. J. Arnscheidt thanks Dietrich Uhlmann and Jürgen Benndorf for inspiring the interest in filter feeders.

\section{Author contributions}

TO, JA and JD designed the project. TO carried out the conjugation experiments, analysed and interpreted results, and performed statistical analyses. MM performed the selection for Rifampicin resistance in the 
ST02013 ${ }^{\text {Rif }}$ strain and conducted all antibiotic susceptibility tests on the strains in this study. TO and MM performed DNA extraction and PCR amplification. All authors contributed to writing the paper.

\section{Conflict of Interest}

The authors declare that there are no conflicts of interest in the preparation of this article. The materials presented represent an original piece of work and have not be submitted to other journals for publication.

\section{References}

1. World Health Organization. Antimicrobial Resistance: Global Report on Surveillance 2014. http://ww w.who.int/drugresistance/documents/surveillancereport/en/.

2. Berendonk TU, Manaia CM, Merlin C, Fatta-Kassinos D, Cytryn E and Walsh F., et al. (2015). Tackling antibiotic resistance: the environmental framework. Nat Rev Microbiol. 2015;13:310-317.

3. Taylor NGH, Verner-Jeffreys DW and Baker-Austin C. Aquatic systems: maintaining, mixing and mobilising antimicrobial resistance? Trends Ecol Evol. 2011;26:278-284.

4. Czekalski N, Sigdel R, Birtel J, Matthews B and Bürgmann H. Does human activity impact the natural antibiotic resistance background? Abundance of antibiotic resistance genes in 21 Swiss lakes. Environ Int. 2015;81:45-55

5. Pruden A, Arabi M, Storteboom HN. Correlation between upstream human activities and riverine antibiotic resistance genes. Environ Sci Technol. 2012;46:11541-11549 
6. Proia L, von Schiller D, Sànchez-Melsió A, Sabater S, Borrego CM and Rodríguez-Mozaz S et al. Occurrence and persistence of antibiotic resistance genes in river biofilms after wastewater inputs in small rivers. Environ Pollut. 2016;210:121-128

7. Chen B, Liang X, Huang X, Zhang T and Li X. Differentiating anthropogenic impacts on ARGs in the Pearl River Estuary by using suitable gene indicators. Water Res. 2013;47:2811-2820.

8. Bouki C, Venieri D and Diamadopoulos E. (2013). Detection and fate of antibiotic resistant bacteria in wastewater treatment plants: A review. Ecotox Env Safety. 2013;91:1-9.

9. Manaia CM, Rocha J, Scaccia N, Marano R, Radu E and Biancullo F et al. Antibiotic resistance in wastewater treatment plants: tackling the black box. Environ Int. 2018;115:312-324.

10. Marti E, Variatza E, and Balcazar JL. The role of aquatic ecosystems as reservoirs of antibiotic resistance. Trends Microbiol. 2014;22(1):36-41.

11. Lupo A, Coyne S and Berendonk T. Origin and evolution of antibiotic resistance: the common mechanisms of emergence and spread in water bodies. Front Microbiol. 2012;3(18):115-128.

12 Hadas O, Cavari BZ, Kott Y and Bachrach U. Preferential feeding behaviour of Daphnia magna. Hydrobiologia. 1982;89:49-52.

13 Sison-Mangus MP, Mushegian AA and Ebert D. Water fleas require microbiota for survival, growth and reproduction. The ISME Journal. 2015;9:59-67.

14 Hall BG and Barlow M. Evolution of the serine beta-lactamases: past, present and future. Drug Resist Updat. 2004; 7: 111-123.

15. Yin XM and Stotzky G. Gene transfer among bacteria in natural environments. Adv Appl Microbiol. 1997;45:153-212. 
16. Santagati M, Campanile F and Stefani S. Genomic diversification of Enterococci in Hosts: the role of the mobilome. Front Microbiol. 2012;3:95.

17. Fu J, Yang D, Jin M, Liu W, Zhao X and Li C. et al. Aquatic animals promote antibiotic resistance gene dissemination in water via conjugation: Role of different regions within the zebra fish intestinal tract, and impact on fish intestinal microbiota. Mol Ecol. 2017;26:5318-5333.

18. Huddleston JR. Horizontal gene transfer in the human gastrointestinal tract: potential spread of antibiotic resistance genes. Infect Drug Resist. 2014;7:167-176.

19. Deller S, Mascher F, Platzer S, Reinthaler FF and Marth E. Effect of solar radiation on survival of indicator bacteria in bathing waters. Cent Eur J Public Health. 2006;14:133-137.

20. Byappanahalli MN, Nevers MB, Korajkic A, Staley ZR and Harwood VJ. Enterococci in the Environment. Microbiol Mol Rev. 2012;76(4):685-706

21. Franz CM, Huch M, Abriouel H, Hozapfel W and Gàlvez A. Enterococci as probiotics and their implications in food safety. Int J Food Microbiol. 2011;151(2):125-140.

22. Guzman Prieto AM, van Schaik W, Rogers MR, Coque TM, Baquero F and Corander J. et al. Global emergence and dissemination of enterococci as nosocomial pathogens: attack of the clones? Front Microbiol. 2016;7:788.

23. Wade TJ, Calderon RL, Sams E, Beach M. Brenner KP and Williams, AH et al (2006). Rapidly measured indicators of recreational water quality are predictive of swimming-associated gastrointestinal illness. Environ Health Perspect. 2006;114:24-28.

24. Mannu L, Paba A, Daga E, Comunian R, Zanetti S and Dupre I et al (2003). Comparison of the incidence of virulence determinants and antibiotic resistance between Enterococcus faecium strains of dairy, animal and clinical origin. Int J Food Microbiol. 2013;88:291-304. 
25. Clewell DB. Movable genetic elements and antibiotic resistance in enterococci. Eur J Clin Microbiol Infect Dis. 1990;9:90-102.

26. Conwell M, Daniels V, Naughton PJ and Dooley JSG. Interspecies transfer of vancomycin, erythromycin, and tetracycline resistance among Enterococcus species recovered from agrarian sources. BMC Microbiol. 2017;17(1):19.

27. Hirt H, Greenwood-Quaintance KE, Karau MJ, Till LM, Kashyap PC and Patel R et al. Enterococcus faecalis Sex Pheromone cCF10 Enhances Conjugative Plasmid Transfer In Vivo. mBio 2018;9(1):e0003700018.

28. Daniels V. PhD Thesis: antibiotic resistant bacteria in Irish waters: molecular epidemiology and hydrological control. University of Ulster, 2011. http://ethos.bl.uk/OrderDetails.Do?ui n= uk.bl.ethos.551 508.

29. EUCAST Clinical Breakpoints and Dosing of Antibiotics. http://www.eucast.org/fileadmin/src/med ia/PDFs/EUCAST_files/Breakpoint_tables/v_8.1_Breakpoint_tTables.pdf

30. CLSI Breakpoints. http://www.oxoid.com/pdf/uk/2013-CLSIFDA-table-update.pdf via standard document: CLSI document M100-S23 (M02-A11) 31. Culver DA, Boucherle MM, Bean DJ, and Fletcher JW. Biomass of freshwater crustacean zooplankton from length-weight regressions. Can J Fish Aquat Sci. 1985;42:1380-1390.

32. Dukić M, Berner D, Roesti M, Haag CR and Ebert D. A high-density genetic map reveals variation in recombination rate across the genome of Daphnia magna. BMC Genet. 2016;17:137.

33. OECD. Test No. 202: Daphnia sp. Acute Immobilisation Test, OECD Guidelines for the Testing of Chemicals, Section 2, OECD Publishing, Paris, 2004. http://dx.doi.org/10.1787/9789264069947-en.

34. Peterson BJ. Daphnia grazing on natural bacteria. Limnol Oceanogr. 1978;23(5):1039-1044. 
35. Eckert EM and Pernthaler J. Bacterial epibionts of Daphnia: a potential route for the transfer of dissolved organic carbon in freshwater food webs. The ISME Journal. 2014;8:1808-1819.

36. Brendelberger H. Filter mesh size of cladocerans predicts retention efficiency for bacteria. Limnol Oceanogr. 1991;36(5):884-894.

37. Urabe $\mathrm{J}$ and Watanabe $\mathrm{Y}$. Effect of food conditions on the bacterial feeding of Daphnia galeata. Hydrobiologia. 1991;225:121-128.

38. Burns CW. The relationship between body size of filter-feeding Cladocera and the maximum size of particle ingested. Limnol Oceanogr. 1968;13:675-678.

39. Gophen M and Geller W. Filter mesh size and food particle uptake by Daphnia. Oecologia. 1984; 64: 408-412.

40. Dunny GM. Enterococcal sex pheromones: signalling, social behaviour, and evolution. Ann Rev Genet. 2013;47:457-482.

41. Werner G, Freitas AR, Coque TM, Sollid JE, Lester C and Hammerum, AM et al. Host range of enterococcal vanA plasmids among gram-positive intestinal bacteria. J Am Chem. 2010;66(2):273-282.

42. Toğay SO. Temiz A, Çelebi A, Açik L and Yalçin SS (2014). Investigation of potential virulence genes and antibiotic resistance characteristics of Enterococcus faecalis isolates from human milk and colostrum samples. Turk J Biol. 2014;38:357-364.

43. Moubareck C, Bourgeois N, Courvalin P and Doucet-Populaire F. Multiple antibiotic resistance gene transfers from animal to human enterococci in the digestive tract of gnotobiotic mice. Antimicrob Agents Chemother. 2003;47:2993-2996. 
44. de Niederhäusern S, Bondi M, Messi P, Iseppi R, Sabia C and Manicardi G et al. Vancomycinresistance transferability from VanA enterococci to Staphylococcus aureus. Curr Microbiol. 2011;62:1363-1367.

45. van Tyne D and Gilmore MS. Friend Turned Foe: Evolution of Enterococcal Virulence and Antibiotic Resistance. Ann Rev Microbiol. 2014;68:337-356.

46. Anacarso I, Iseppi R, Sabia C, Messi, P, Condò C and Bondi M et al. Conjugation-mediated transfer of antibiotic-resistance plasmids between Enterobacteriaceae in the digestive tract of Blaberus craniifer (Blattodea: Blaberidae). J Med Entomol. 2016;53(3):591-597.

47. Suzuki S, Makihara N and Kadoya A. Tetracycline resistance gene tet(M) of a marine bacterial strain is not accumulated in bivalves from seawater in clam tank experiment and mussel monitoring. Sci Tot Environ. 2018;634:181-187

48. Eckert EM, Cesare AD. Stenzel B, Fontaneto D and Corno G. Daphnia as a refuge for an antibiotic resistance gene in an experimental freshwater community. Sci Tot Environ. 2016;571:77-81.

49. Vijverberg J and Richter AS. Population dynamics and production of Daphnia hyalina Leydig and Daphnia cucullata Sars in Tjeukemeer. Hydrobiologia. 1982; 95: 235-259. 


\section{Figures and captions}

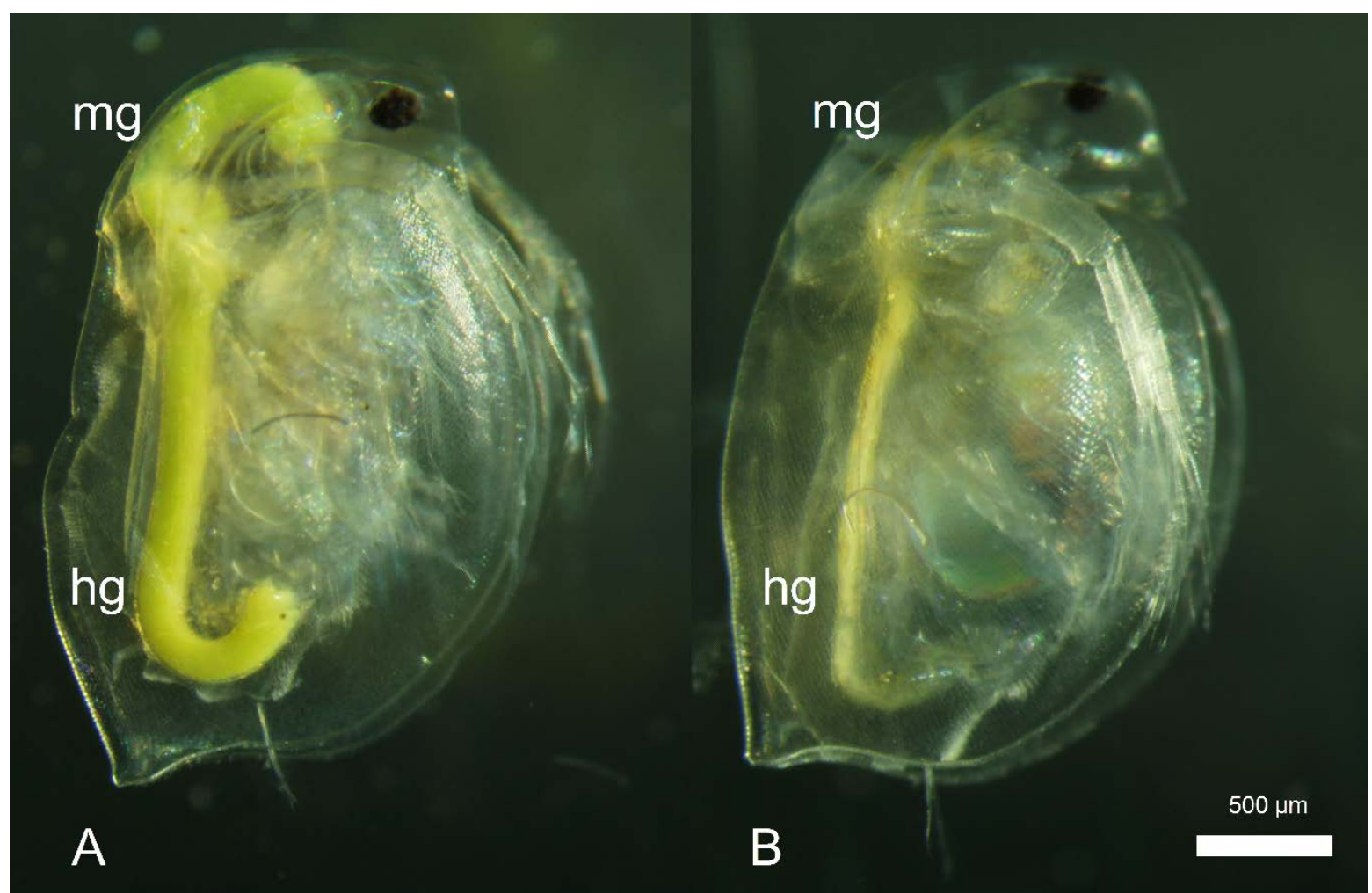

Fig. 1

Microscopic image of Daphnia magna before (A) and after gut clearance (B). Daphnids were grown on a Desmodesmus subspicatus diet. Gut clearance was achieved by 24 h starvation and $72 \mathrm{~h}$ filtration of Sephadex gel beads (mg = mid gut; hg = hind gut). 


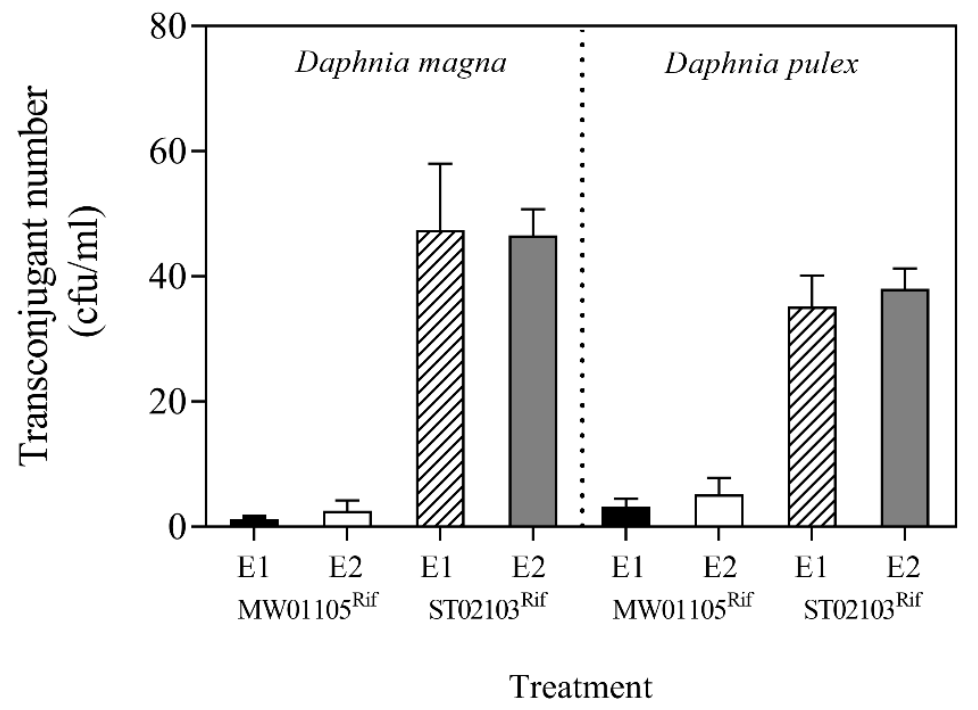

Fig. 2: Emergence of vancomycin resistant transconjugants from Daphnia-bacteria treatments in two experiments $(\mathrm{E} 1=$ experiment $1, \mathrm{E} 2=$ experiment 2$)$ as total $\mathrm{cfu}$ from feeding and gut clearance phases. Samples $(\mathrm{n}=7)$ of 10 daphnids from species $D$. magna or $D$. pulex were held in E. faecalis treatments containing donor and individual recipient strains (MW01105 ${ }^{\text {Rif }}$ or ST02103 ${ }^{\text {Rif }}$ ) for $4 \mathrm{~h}$ and were subsequently transferred into liquid without bacteria for $2 \mathrm{~h}$ gut clearance. Transconjugants were isolated on vancomycin and rifampicin double-selection agar plates. Bar $=$ mean number of transconjugants at 95\% confidence interval. Error bars $=$ standard error of the mean. 


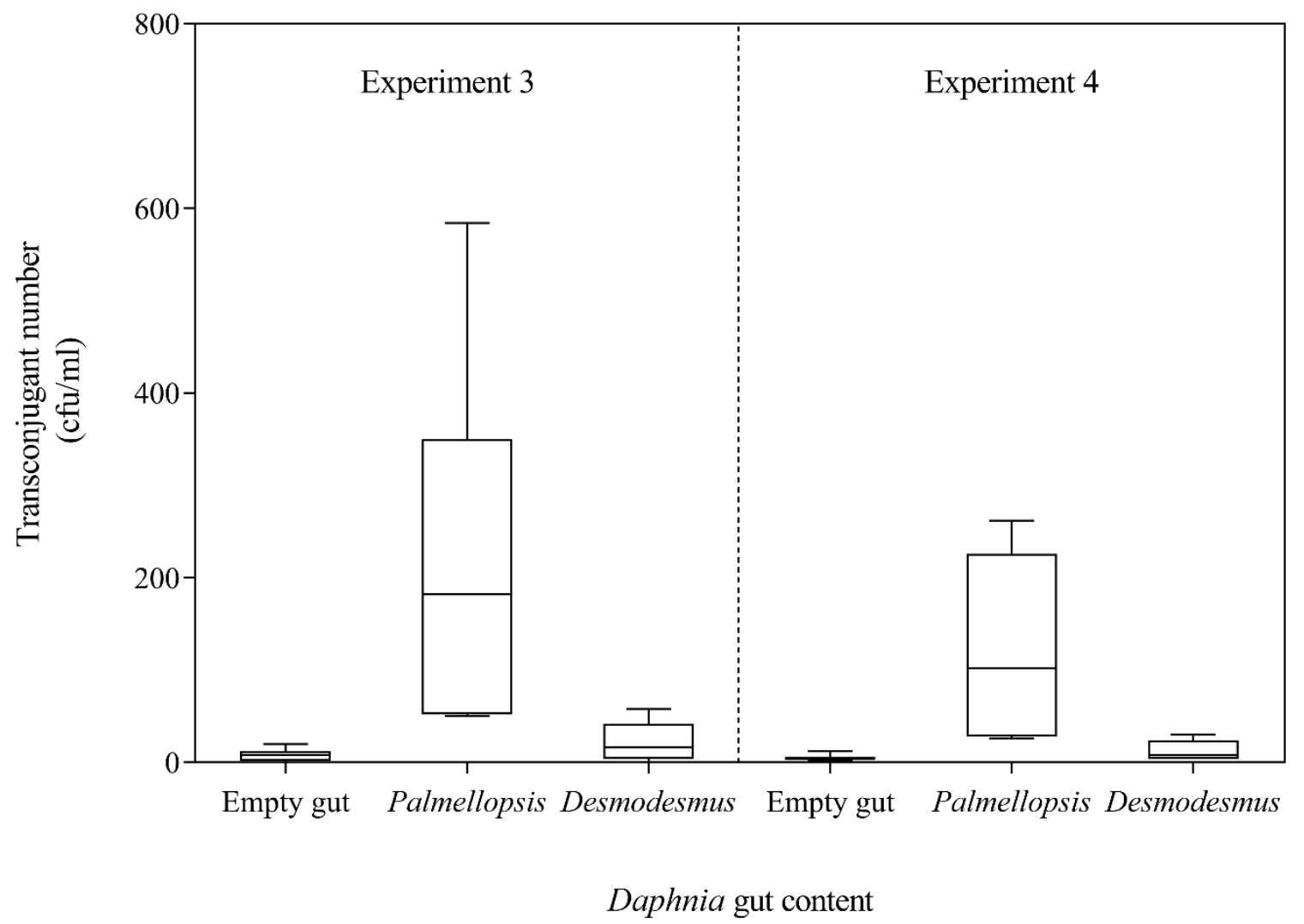

Fig. 3: Emergence of vancomycin resistant transconjugants from Daphnia magna-bacteria treatments in two experiments as total cfu from feeding and gut clearance phases. Treatments differed in the diets before exposure to bacteria, as Daphnia were fed Desmodesmus subspicatus, Palmellopsis sp.; unfed specimens with empty guts were used as control. Samples ( $\mathrm{n}=7$ ) of 10 daphnids were held in E. faecalis treatments containing donor and recipient strain MW01105 ${ }^{\text {Rif }}$ for $4 \mathrm{~h}$ and were subsequently transferred into liquid without bacteria for $2 \mathrm{~h}$ gut clearance. Transconjugants were isolated on vancomycin and rifampicin selection agar plates. In each box and whisker plot, the centre line marks the median transconjugant count. Length of each box represents the range of transconjugant counts obtained from seven samples per treatment, with box edges at the $25^{\text {th }}$ and $75^{\text {th }}$ percentiles. Whiskers indicate the minimum and maximum transconjugant counts. 


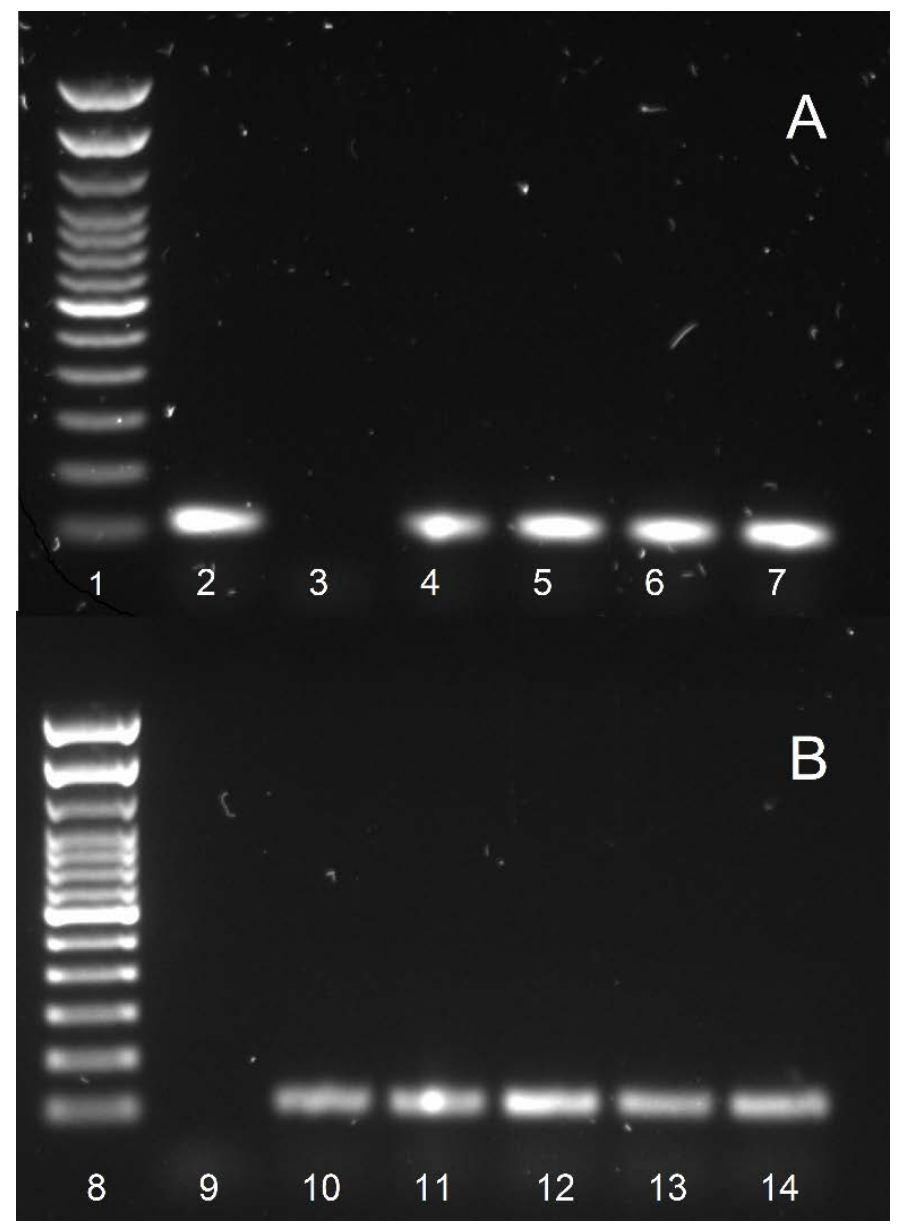

\section{Supplementary Fig. S1}

Agarose gel electrophoresis of the PCR amplification of a vanA gene in parent E. faecalis strains and transconjugants obtained from conjugation experiments with (A) recipient strain MW01105 and (B) recipient strain ST02013. Lane 1: 100 bp molecular size marker; Lane 2: vanA gene in donor MF06036; Lane 3: vanA gene not detected in recipient strain MW01105; Lane 4-5: vanA gene in transconjugants of MW01105 obtained from Daphnia magna; Lane 6-7: vanA gene in transconjugants obtained from Daphnia pulex; Lane 8: 100 bp molecular size marker ; Lane 9: vanA gene not detected in recipient ST02013; Lane 10: vanA gene in donor MF06036; Lane 1112: vanA gene in transconjugants obtained from Daphnia magna; Lane 13-14: vanA gene in transconjugants obtained from Daphnia pulex. 
a. MF06036

b. MW01105trans

c. ST02103trans
- GCTACGTTTACCTATCCTGTTTTTGTTAAGCCGGCGCGTTCAGGCTCATCCT - - - AGCTACGTTTACCTATCCTGTTTTTGTTAAGCCGGCGCGTTCAGGCTCATCCTTCGG ........................... AAGCCGGCGCGTTCAGGCTCATCCTTCG -

\section{Supplementary Fig. S2}

CLUSTAL W (1.83) multiple sequence alignment for vanA gene in (a) MF06036 ${ }^{\text {Van }}$ (b) MW01105 ${ }^{\text {Rif }}$ transconjugant and (c) ST02013 ${ }^{\text {Rif }}$ transconjugant from a Daphnia magna conjugation experiment

\section{Tables and table captions}

Table 1: Disk diffusion antimicrobial resistance profiles of selected Enterococcus faecalis isolates

\begin{tabular}{l|c|c|c|c|c|c|c|c}
\hline \multirow{2}{*}{$\begin{array}{l}\text { Enterococcus } \\
\text { isolate }\end{array}$} & CIP & IMP & LIN & $*$ RD & S & TEI & TRI & VAN \\
\cline { 2 - 9 } & & & & & & & & \\
\hline MF06036 $^{\text {Van }}$ & S & S & S & S & R & R & I & R \\
\hline MW01105 $^{\text {Rif }}$ & S & S & S & R & R & S & I & S \\
\hline ST02013 $^{\text {Rif }}$ & S & S & S & R & R & R & I & S \\
\hline
\end{tabular}

CIP - Ciprofloxacin, IMP - Imipenem, LIN - Linezolid, RD - Rifampicin, S - Streptomycin, TEI - Teicoplanin, TRI Trimethoprim, VAN - Vancomycin

R - Resistant, I - Intermediate, S - Susceptible

EUCAST ECOFF breakpoint values were used as guidelines for all susceptibility interpretations except rifampicin (RD)

*Rifampicin (RD) resistance/susceptibility was determined in accordance with CLSI breakpoint values 
Table 2: Arithmetic means $(\mathrm{n}=3)$, standard deviations and estimates for $95 \%$ confidence intervals for filtration rates in different Daphnia - Enterococcus faecalis treatments (strains MW01105 ${ }^{\text {Rif }}$, ST02103 ${ }^{\text {Rif }}$ )

\begin{tabular}{lccc}
\hline & M & SEM & $\begin{array}{c}95 \% \text { CI for } \\
\text { Mean } \\
\text { Difference }\end{array}$ \\
\hline $\begin{array}{l}\text { Filtration rate of } D . \text { magna } \\
\left(\mathrm{mL} \mathrm{ind}^{-1} \mathrm{~h}^{-1}\right)\end{array}$ & 0.031 & 0.004 & $0.0217,0.0401$ \\
$\begin{array}{l}\text { MW01105 Rif } \\
\text { ST02103 }\end{array}$ & 0.031 & 0.001 & $0.0285,0.0334$ \\
$\left.\begin{array}{l}\text { Filtration rate of } D . \text { pulex } \\
(\mathrm{mL} \text { ind }\end{array} \mathrm{h}^{-1}\right)$ & & & \\
MW01105 $^{\text {Rif }}$ & 0.025 & 0.0012 & $0.0219,0.0289$ \\
ST02103 $^{\text {Rif }}$ & 0.026 & 0.0015 & $0.0226,0.0302$ \\
\hline
\end{tabular}

$\mathrm{M}=$ arithmetic mean; SEM = Standard error of mean ; C.I. = confidence interval 
Table 3: Mean transfer efficiencies $(\mathrm{n}=7)$ of vancomycin resistance to recipient Enterococcus faecalis strains MW01105 ${ }^{\text {Rif }}$, ST02103 ${ }^{\text {Rif }}$ within the gut of two Daphnia species

\begin{tabular}{|c|c|c|c|c|c|c|}
\hline & $\begin{array}{l}\text { Recipient } \\
\text { strains }\end{array}$ & $\begin{array}{l}\text { Donor count } \\
\text { (CFU/mL) }\end{array}$ & $\begin{array}{c}\text { Recipient } \\
\text { count } \\
(\mathrm{CFU} / \mathrm{mL})\end{array}$ & $\begin{array}{c}\text { Transconjugant } \\
\text { number } \\
\text { (cfu/mL) } \\
\text { FP+GCP (T) }\end{array}$ & $\begin{array}{l}\text { Transfer } \\
\text { efficiency } \\
\text { (T:R) }\end{array}$ & $\begin{array}{l}\text { Transfer } \\
\text { efficiency } \\
\text { (T:D) }\end{array}$ \\
\hline \multicolumn{7}{|c|}{ Experiment 1} \\
\hline \multirow[t]{2}{*}{ D. magna } & MW01105 Rif & $1.8 \times 10^{8}$ & $1.7 \times 10^{8}$ & $3+0(3)$ & $1.51 \times 10^{-8}$ & $1.4 \times 10^{-8}$ \\
\hline & ST02103Rif & $1.4 \times 10^{8}$ & $1.5 \times 10^{8}$ & $45+2(47)$ & $3.16 \times 10^{-7}$ & $3.35 \times 10^{-7}$ \\
\hline \multirow[t]{2}{*}{ D. pulex } & MW01105 Rif & $1.8 \times 10^{8}$ & $1.7 \times 10^{8}$ & $3+0(3)$ & $1.85 \times 10^{-8}$ & $1.71 \times 10^{-8}$ \\
\hline & ST02103 Rif & $1.8 \times 10^{8}$ & $1.5 \times 10^{8}$ & $32+3(35)$ & $1.92 \times 10^{-7}$ & $2.33 \times 10^{-7}$ \\
\hline \multicolumn{7}{|c|}{ Experiment 2} \\
\hline \multirow[t]{2}{*}{ D. magna } & MW01105 Rif & $1.1 \times 10^{8}$ & $1.1 \times 10^{8}$ & $1+0(1)$ & $1.11 \times 10^{-8}$ & $1.08 \times 10^{-8}$ \\
\hline & ST02103Rif & $1.1 \times 10^{8}$ & $1.1 \times 10^{8}$ & $40+6(46)$ & $4.37 \times 10^{-7}$ & $4.51 \times 10^{-7}$ \\
\hline \multirow[t]{2}{*}{ D. pulex } & MW01105 Rif & $1.1 \times 10^{8}$ & $1.1 \times 10^{8}$ & $5+0(5)$ & $4.98 \times 10^{-8}$ & $4.84 \times 10^{-8}$ \\
\hline & ST02103 Rif & $1.1 \times 10^{8}$ & $1.1 \times 10^{8}$ & $36+2(38)$ & $3.56 \times 10^{-7}$ & $3.68 \times 10^{-7}$ \\
\hline
\end{tabular}

$\mathrm{FP}=$ Feeding phase $; \mathrm{GCP}=$ Gut clearance phase; $\mathrm{T}=$ mean total transconjugant number; $\mathrm{D}=$ donor count; $\mathrm{R}=$ recipient count 
Table 4: Mean transfer efficiencies $(\mathrm{n}=7)$ of vancomycin resistance to recipient Enterococcus faecalis strain MW01105 ${ }^{\text {Rif }}$ in Daphnia magna depending on the ingestion of individual phytoplankton species before filtering bacteria

\begin{tabular}{|c|c|c|c|c|c|}
\hline Gut content & $\begin{array}{l}\text { Donor count } \\
(\mathrm{cfu} / \mathrm{mL})\end{array}$ & $\begin{array}{l}\text { Recipient count } \\
(\mathrm{cfu} / \mathrm{mL})\end{array}$ & $\begin{array}{c}\text { Transconjugant number } \\
(\mathrm{cfu} / \mathrm{mL}) \\
\text { FP + GCP (T) }\end{array}$ & $\begin{array}{l}\text { Transfer efficiency } \\
\text { (T:R) }\end{array}$ & $\begin{array}{c}\text { Transfer } \\
\text { efficiency (T:D) }\end{array}$ \\
\hline \multicolumn{6}{|l|}{ Experiment 3} \\
\hline No algae & $1.0 \times 10^{8}$ & $1.4 \times 10^{8}$ & $4+4(8)$ & $5.6 \times 10^{-8}$ & $8.6 \times 10^{-8}$ \\
\hline $\begin{array}{l}\text { Desmodesmus } \\
\text { subspicatus }\end{array}$ & $1.0 \times 10^{8}$ & $1.4 \times 10^{8}$ & $20+2(22)$ & $1.5 \times 10^{-7}$ & $2.4 \times 10^{-7}$ \\
\hline Palmellopsis sp & $1.0 \times 10^{8}$ & $1.4 \times 10^{8}$ & $65+165(230)$ & $1.6 \times 10^{-6}$ & $2.5 \times 10^{-6}$ \\
\hline \multicolumn{6}{|l|}{ Experiment 4} \\
\hline No algae & $1.1 \times 10^{8}$ & $1.1 \times 10^{8}$ & $4+1(5)$ & $4.71 \times 10^{-8}$ & $4.57 \times 10^{-8}$ \\
\hline $\begin{array}{l}\text { Desmodesmus } \\
\text { subspicatus }\end{array}$ & $1.1 \times 10^{8}$ & $1.1 \times 10^{8}$ & $12+1(13)$ & $1.26 \times 10^{-7}$ & $1.22 \times 10^{-7}$ \\
\hline Palmellopsis sp & $1.1 \times 10^{8}$ & $1.1 \times 10^{8}$ & $113+5(118)$ & $1.08 \times 10^{-6}$ & $1.05 \times 10^{-6}$ \\
\hline
\end{tabular}

$\mathrm{FP}=$ Feeding phase, $\mathrm{GCP}=$ Gut clearance phase, $\mathrm{T}=$ mean total transconjugant number obtained from seven samples 